\title{
Proximate composition of pumpkin gourd (Cucurbita pepo) seeds from Zimbabwe
}

\author{
Raphael Kwiri, Clive Winini, Amos Musengi, Misheck Mudyiwa, Clarice Nyambi, \\ Perkins Muredzi, Abigail Malunga
}

Department of Food Processing Technology, School of Industrial Science \& Technology, Harare Institute of Technology, Ganges Rd, Box BE 277, Belvedere, Harare, Zimbabwe

\section{Email address:}

rkwiri@hit.ac.zw (R. Kwiri), cwinini@hit.ac.zw (C. Winini), amusengi@hit.ac.zw (A. Musengi), mmudyiwa@hit.ac.zw (M. Mudyiwa), cnyambi@hit.ac.zw (C. Nyambi), pmuredzi@hit.ac.zw (P. Muredzi), amalunga@hit.ac.zw (A. Malunga)

\section{To cite this article:}

Raphael Kwiri, Clive Winini, Amos Musengi, Misheck Mudyiwa, Clarice Nyambi, Perkins Muredzi, Abigail Malunga. Proximate Composition of Pumpkin Gourd (Cucurbita Pepo) Seeds from Zimbabwe. International Journal of Nutrition and Food Sciences. Vol. 3, No. 4, 2014, pp. 279-283. doi: 10.11648/j.ijnfs.20140304.17

\begin{abstract}
Curcubita pepo seeds have been widely consumed in Zimbabwe way back in the 1970s, but still locally, there is no data on the nutritional quality of Curcubita pepo seeds, hence the study attempted to avail this information. Curcubita pepo seeds from selected places in Zimbabwe were analysed. The proximate analysis including major nutrients and minerals were determined. The C. pepo seed had a moisture content of $5.662 \pm 0.016 \mathrm{gkg}^{-1}$. Significantly, Curcubita pepo had high amounts of crude oil and proteins as compared to other edible oil rich seeds. The crude oil content and protein were $43.460 \pm 0.098 \mathrm{gkg}^{-1}$ and $32.860 \pm 0.103 \mathrm{gkg}^{-1}$ respectively. Other components such as carbohydrates, crude fibre and energy were $12.160 \pm 0.142 \mathrm{gkg}^{-1}, 2.578 \pm 0.007 \mathrm{gkg}^{-1}$ and $562.82 \pm 0.132 \mathrm{gkg}^{-1}$ correspondingly. Ash content was $3.324 \pm 0.010 \mathrm{gkg}^{-1}$ which was further analysed into various major minerals giving analysed means as $\mathrm{Na}\left(67.956 \pm 0.037 \mathrm{gkg}^{-1}\right)$, $\mathrm{Zn}$ $\left(1.244 \pm 0.010 \mathrm{gkg}^{-1}\right), \mathrm{P}\left(1040.8 \pm 0.663 \mathrm{gkg}^{-1}\right), \mathrm{Fe}\left(11.980 \pm 0.086 \mathrm{gkg}^{-1}\right), \mathrm{Ca}\left(141 \pm 0.316 \mathrm{gkg}^{-1}\right)$ and $\mathrm{Mg}\left(344.6 \pm 0.245 \mathrm{gkg}^{-1}\right)$. The findings indicated that $C$. pepo seeds are a good alternative source of highly nutritious food for instance proteins and lipids as well as minerals ( $\mathrm{Mg}, \mathrm{Ca}, \mathrm{Zn}, \mathrm{P}$ and $\mathrm{Fe}$ ) that could greatly contribute to human nutritional requirements. However, it still remains important to further profile the quality of the lipids and proteins from C. pepo seed so as to verify their essentiality and availability to the human body as well as evaluating the presence of other bioactive and antinutritional factors that might be present in these seeds.
\end{abstract}

Keywords: Proximate, Cucurbita Pepo, Nutrition, Seed

\section{Introduction}

Knowledge of the nutritive value of local dishes, soup ingredients and local foodstuffs is necessary in order to encourage the increased cultivation and consumption of those that are highly nutritive. Consumption of nutritive local foodstuffs will help to supplement the nutrients of the staple carbohydrate foods of the poor who cannot afford enough protein foods of animal origin [1;2]. Moreover, Cucurbits are widely grown in Southern Africa [22]. Achu et al. (2013) reported that, pumpkins can be grown in both temperate and tropical regions.

Pumpkin, belonging to the genus Cucurbita and family Cucurbitaceae refers to any one of the species Cucurbita moschata, Cucurbita mixta, Cucurbita maxima, and Cucurbita pepo [3]. Pumpkin (C. pepo) is mostly used to refer to cultivars with round fruits which are used in the mature state for baking or feeding livestock [7]. Pumpkin is among the economically most important vegetable crops worldwide and is grown in both temperate and tropical regions. Depending upon the species, virtually all parts of the plant can be used for food, including leaves, shoots, roots, flowers, seeds, and immature and mature fruits [28].

The nutritional value of the Cucurbitaceae seeds is dependent on the strain, species type as well as climatic conditions where it is grown [28]. From a study conducted in Cameroon, the results confirmed the strain dependency of the nutritional value of Cucurbitaceae seeds from various species namely, Cucumeropsis mannii, Cucurbita maxima, Cucurbita moschata, Lagenaria siceraria and 
Cucumis sativus [2]. Studies on Cucurbitaceae seeds and their defatted cakes are rich in proteins (28 to 40.49 and 61 to $73.59 \%$ respectively). They also contain high lipid levels similar to those of the other oilseeds. These seeds can thus be considered as sources of proteins and oils [2] Loukou et al., (2007) also found similar results with Cucurbit seeds from Côte d'Ivoire where they found that these seeds had protein levels ranging from 29 to $36 \%$. However, it was reported that Cucurbit seeds from Sudan had a low protein content ranging from $14-17.5 \%$, and from these findings the nutritional content of these seeds depends on the regions as enhanced by the low values obtained from Sudanese seeds. In addition to remarkable nutritive value of Cucurbitaceae seeds, they do have other uses such as soup thickeners and also when cooked, toasted/roasted and dried, can serve as snacks. Moreover, they are less expensive and widely distributed and can therefore be easily cultivated and consumed or sold by the masses. Seeds of pumpkins can also be roasted as a snack and made into a paste that resembles peanut butter $[1 ; 21]$, for instance in Zimbabwe this has been the traditional practice and even to date.

Seeds from Cucurbita and family Cucurbitaceae including Cucurbita pepo contain bioactive compounds which have antifatigue activity and can elevate exercise performance. The seeds were said to have bioactivities such as hepatoprotection, anti-diabetes, anticancer, and anti-obesity properties [25].

In Zimbabwe Curcubita pepo seeds are consumed widely mainly in summer as a snack, however, there remains no data on the nutritional quality of Curcubita реро seeds, therefore the present study attempted to determine the proximate composition of dry seeds.

\section{Materials and Methods}

\subsection{Samples Collection and Preparation}

A total of 100 samples were collected from five districts namely Mazowe, Shamva, Mtoko, Mrehwa and Domboshava where a total of twenty Curcubitae pepo fruits were collected per each district. The fruits were identified as Curcubitae pepo (Mubovora/Munhanga in Shona,) [19] or (ibobola in Ndebele) at National Herbarium and Botanical Gardens, Harare, Zimbabwe. The districts selected present ideal climatic conditions for the growing of Curcubitae pepo fruit. The Curcubitae pepo fruits selected were mature, fresh and ready for the market. The selected fruits were immediately transported to the Food Laboratory at Harare Institute of Technology within one day of sampling. In the laboratory the seeds were recovered from the Curcubitae pepo fruits within two days of arrival. The seeds were dried using a solar dryer until their moisture content was approximately $10 \%$. Despite different sources of the fruits, the seeds were homogeneously mixed and sent to a national standards laboratory where nutritional composition of the seeds was determined. Sample analysis commenced within 15 days after recovery from the fruit. Samples analysis was done in triplicates and reported as mean \pm standard error of the mean

\subsection{Sample Analysis}

Proximate analysis was carried out using the AOAC (1990) [4] standard methods which are for quantifying nutrients in samples. Moisture was determined by oven drying method (Gallenkamp, plus II oven, Germany) using a representative sample of $5 \mathrm{~g}$ Curcubitae pepo seeds at $105^{\circ} \mathrm{C}$ until constant weight was obtained (Sadiq et al., 2013). Crude proteins were estimated by an NCS- elementary analyser Flash 2000 (Flash 2000 Organic Elemental Analyser, Germany). Total proteins were automatically calculated by the machine by multiplying the estimated nitrogen content by 6.25 as the appropriate conversion factor. Crude fat content was determined using Soxhlet apparatus using hexane as organic solvent. The extraction was performed for 14 hours and hexane was later recovered by drying the sample in an oven (Gallenkamp, plus II oven, Germany) set at $110{ }^{\circ} \mathrm{C}$ for 30 minutes. To determine crude fibre a $5 \mathrm{~g}$ sample of dried sample was digested with 1.25 M sulphuric acid and 1.25 M sodium hydroxide solution. The insoluble residue obtained was washed with hot water and dried in an oven (Gallenkamp, plus II oven, Germany) at $105^{\circ} \mathrm{C}$ until constant weight. The dried residue was then incinerated, and weighed for the determination of crude fibres content. Available carbohydrate and calorific value are determined by calculation $[4 ; 5 ; 12]$. For percentage carbohydrates the following formula was used: \% Carbohydrates: $100-(\%$ moisture $+\%$ proteins $+\%$ lipids $+\%$ ash $+\%$ fibres $)$. The energy value was determined using the AOAC (1990)[4] formula: Energy $=(\mathrm{g}$ protein $\mathrm{x} 2.44)+(\mathrm{g}$ lipid $\mathrm{x}$ carbohydrate x $8.37 \times 3.57$ ).

Ash content was determined by initially charring the $5 \mathrm{~g}$ dried homogenous powdered sample in a muffle furnace (Carbolite RHS 1600 , Germany) at $250{ }^{\circ} \mathrm{C}$ until the sample turned black. Thereafter, the sample was incinerated in the same muffle furnace (Carbolite RHS 1600, Germany) at $550{ }^{\circ} \mathrm{C}$ for 5 hours until the ash turned white. The results of water content were expressed on wet sample basis while those of ash, fibre, protein, lipid and carbohydrate contents were expressed on dry matter basis [10].

\subsection{Mineral Analysis}

Mineral analysis ( $\mathrm{Ca}, \mathrm{Mg}, \mathrm{Na}, \mathrm{Fe}, \mathrm{Zn}$, and $\mathrm{P}$ ) was performed by inductive coupled plasma atomic emission spectroscopy (iCap 6000 series, Germany) [14]. Mineral analysis was carried out using the ash obtained during ashing of the $(5 \mathrm{~g})$ sample. The ash obtained was dissolved in $5 \mathrm{~mL}$ of hydrochloric acid /nitric acid and analysed thereafter using ICP-spectroscopy.

\subsection{Statistical Analysis}

All the statistical analyses were performed and data presented as an average of triplicate readings. Data was analysed using EXCEL (MicroSoft) and presented as mean \pm standard error of the mean. 


\section{Results}

Tables 1 and 2 give a summary of the main results of this study and Table 1 gives a comparison with previous studies.

Table 1. Proximate composition of Curcubita pepo

\begin{tabular}{lll}
\hline Components $(\%)$ & ${ }^{*} \mathbf{C}_{\mathbf{m}}$ Dried seeds & Other Studies** \\
\hline Water content & $5.662 \pm 0.016$ & 5.149 \\
Crude Ash & $3.324 \pm 0.010$ & 5.315 \\
Crude Fibre & $2.578 \pm 0.007$ & 10.851 \\
Crude Protein & $32.860 \pm 0.103$ & 29.811 \\
Crude Fat & $43.460 \pm 0.098$ & 45.676 \\
Carbohydrates & $12.160 \pm 0.142$ & 14.019 \\
Energy $(\mathrm{kCal} / 100 \mathrm{~g})$ & $562.82 \pm 0.132$ & 559 \\
\hline
\end{tabular}

${ }^{*} \mathrm{C}_{\mathrm{m}}$ Dried seeds readings expressed as Mean \pm standard error of the mean. ** Source: Kim et al., (2007)

Table 2. Mineral composition of Curcubita pepo

\begin{tabular}{ll}
\hline Element (mg/100g) & dried seeds \\
\hline Sodium & $67.956 \pm 0.037$ \\
Iron & $11.980 \pm 0.086$ \\
Phosphorous & $1040.8 \pm 0.663$ \\
Calcium & $141 \pm 0.316$ \\
Zinc & $1.244 \pm 0.010$ \\
Magnesium & $344.6 \pm 0.245$ \\
\hline
\end{tabular}

* Readings expressed as Mean \pm standard error of the mean

The nutritional quality of Curcubita pepo from selected places in Zimbabwe was profiled on the basis of major nutritional components (reported as percentages) such as proteins, fats, carbohydrates, fibre and gross ash, and further itemised into major minerals (reported as $\mathrm{mg} / 100 \mathrm{~g}$ ) including sodium, magnesium, calcium, iron, phosphorus, zinc and magnesium as shown in Tables $1 \& 2$. Also moisture content of the dry seeds was determined. Significantly, Curcubita pepo had high amounts of crude oil and proteins as compared to other edible oil rich seeds. The crude oil and protein content were reported as $43.460 \pm 0.098 \mathrm{gkg}^{-1}$ and $32.860 \pm 0.103 \mathrm{gkg}^{-1}$ respectively. In addition to that, other components such as carbohydrates and crude fibre were $12.160 \pm 0.142 \mathrm{gkg}^{-1}$ and $2.578 \pm 0.007 \mathrm{gkg}^{-1}$ respectively. Moisture content averages at $5.662 \pm 0.016 \mathrm{gkg}^{-1}$. Ash content calculated as average was $3.324 \pm 0.010 \mathrm{gkg}^{-1}$ which was further analysed into various major minerals giving analysed averages as sodium $\left(67.956 \pm 0.037 \mathrm{gkg}^{-1}\right)$, zinc $\left(1.244 \pm 0.010 \mathrm{gkg}^{-1}\right)$, phosphorus $\left(1040.8 \pm 0.663 \mathrm{gkg}^{-1}\right)$, iron $\left(11.980 \pm 0.086 \mathrm{gkg}^{-1}\right)$, calcium $\left(141 \pm 0.316 \mathrm{gkg}^{-1}\right)$ and magnesium $\left(344.6 \pm 0.245 \mathrm{gkg}^{-1}\right)$.

\section{Discussion}

According to Applequist (2006) [6] , Curcubitae pepo (pumpkin) is a vegetable which is unique in that the flesh, skin and the seeds can be consumed as food. From the analysis of the composition of the seed it can be seen that this food source is a notable source of protein, lipid and carbohydrate as well as most of the macronutrients that are required for healthy living (Table 1) [6]. Chigwe and Saka (1991) [9] indicated that pumpkins supply calcium, iron, vitamin $A$, oil $(25-55 \%$, rich in unsaturated oleic and linoleic acids), protein (25 - 35\%) with high amounts of arginine, aspartate and glutamic acid, although they are deficient in lysine and sulphur- containing amino acids (Chigwe and Saka, 1994). An analysis of the parameters listed in Table 1 shows that the composition of the Zimbabwean variety of $C$. pepo does not differ from that reported in literature. Most of the values reported in this study (Table 1) do not differ from those quoted in literature by more than $5 \%$. This is in line with the studies carried out by Achu et al. (2005) [1] and Loukou et al. (2007) [21] (mainly in Côte d'Ivoire) which revealed similar results on the analysis of Cucurbitaceae seeds. For instance, their studies revealed oil and protein content within the ranges of $28-40.49$ and 61 to $73.59 \%$ respectively, while this study gave $43.460 \pm 0.098 \%$ and $32.860 \pm 0.103$. Furthermore, the nutritional value of the Cucurbitaceae seeds is species dependent and is also influenced by climate [28], hence similar results are possible. However, some studies in Sudan revealed very low amounts of proteins content ranging from $14-17.5 \%$, and these results conclusively confirmed the dependency of nutritional content of these seeds to regional climates.

The composition of $C$. pepo seeds in relation to the Recommend Daily Allowance (RDA) values is shown in Table 3.

Table 3. Nutritional analysis of Curcubita pepo with respect to Recommended Daily Allowances

\begin{tabular}{llll}
\hline Parameter & C. pepo & $\begin{array}{l}\text { RDA (and } \\
\text { Reference) }\end{array}$ & $\begin{array}{l}\text { \% of RDA based } \\
\text { on Reference }\end{array}$ \\
\hline & $\begin{array}{l}\text { Per 100g } \\
\text { serving }\end{array}$ & \\
Crude Fibre & $2.58 \mathrm{~g}$ & $120 \mathrm{~g}^{*}$ & 27 \\
Crude Protein & $32 \mathrm{~g}$ & & \\
Crude Fat & $43 \mathrm{~g}$ & & \\
Carbohydrate & $12 \mathrm{~g}$ & $2400 \mathrm{mg}^{* *}$ & 75 \\
$\begin{array}{l}\text { Sodium } \\
\text { Iron }\end{array}$ & $69 \mathrm{mg}$ & $15 \mathrm{mg}$ & \\
Phosphorous & $1040 \mathrm{mg}$ & $1000 \mathrm{mg}$ & 104 \\
Calcium & $141 \mathrm{mg}$ & $1000 \mathrm{mg}$ & \\
Zinc & $1.2 \mathrm{mg}$ & $15 \mathrm{mg}$ & \\
Magnesium & $344 \mathrm{mg}$ & $350 \mathrm{mg}$ & 98 \\
\hline
\end{tabular}

Sources * Adopted from Wolf \& Miller (2008) and ** from http://www.lenntech.com

From Table 3, it is clear that $C$. pepo seeds are an excellent source of phosphorus and magnesium, with a $100 \mathrm{~g}$ serving providing $104 \%$ and $98 \%$, of the Recommended Daily Allowance (RDA). Despite the nutritional and positive health benefits of consuming C. pepo seeds in particular, this vegetable has suffered a poor image and has been generally grouped together with other "poor man's crops" such as cassava and finger millet. Indeed, $C$. реро is widely consumed among the poor rural communities, where it also doubles as a food security commodity for times of drought, but is shunned in the modern, urban settings. 
Besides the immediate benefits of growing curcubits on domestic scale that include improved income for households (Isaboke et al., 2012) and increased food variety arising from their edible leaves, fruit and seeds, there are several reasons why the cultivation of curcubits on a commercial scale may be desirable. These include the fact that that the Curcubita crop matures early and has long shelf life due to easy storage [17] C. pepo can tolerate temperately harsh environmental conditions, resistant to many pests of the cucurbits and it can be grown well in small pieces of land and yield relatively good returns with minimal fertilizer inputs [8], factors which support the notion that the crop has a huge untapped market with high income possibilities [23].

The relatively high fat content of $C$. pepo seeds subtends their utility value as a potential commercial source of edible oil. Compared with other oil-bearing seeds, C. pepo is relatively a good source of triglycerides with $43 \%$ crude fat, which compares favourably with other established sources including cottonseed (18-26\%), linseed (30-48\%), safflower seed (25-35\%) and sunflower seed (19-56\%) (http://www.containerhandbuch.de). C. pepo seeds can thus be considered as sources of proteins and oils. Intra-family analysis also shows that $C$. pepo has slightly higher fat and protein content (43 and 31\%), as compared to $C$. fortidissma $(25-40 \%$ and $22-29 \%$, respectively). However, these differences may also be the result of variations in cultivation, climate and soil profile conditions [20].

While this study focused on the nutritional aspects of the seeds of $C$. pepo (Zimbabwe variety), there is considerable evidence of medicinal properties of benefit to man associated with this plant. For example, El Zawane Kamarudin et al., 2014 showed that the peel of Cucurbita and family Cucurbitaceae possesses antibacterial compounds and could be a potential source for a new class of antibiotics. For instance at cellular level polysaccharide from Curcubita moschata was also shown to effectively inhibit the $\mathrm{H} 2 \mathrm{O} 2$-catalysed decrease of cell viability, lactate dehydrogenase leakage, and malondialdehyde formation $[27 ; 11]$. The polysaccharide also reduced the $\mathrm{H} 2 \mathrm{O} 2$-catalysed decline of superoxide dismutase activity and glutathione depletion in cultured mouse peritoneal macrophages, which, on the overall, indicated that pumpkin polysaccharide possessed significant cytoprotective effect and antioxidative activity [27]. Additionally, Cucurbita and family Cucurbitaceae such as Cucurbita moschata has been found to have anti-inflammatory and antiulcer activity, and this could be the next generation safe and effective anti-inflammatory drugs [13]. C. pepo seeds have also been used in traditional medicine as a vermifuge, for example, in Turkey, pumpkin seeds are used to treat tapeworm, where the dried seeds are eaten on an empty stomach [7].

\section{Conclusion}

The study focuses on proximate analysis of the C. pepo seeds. From the results obtained, C. pepo seeds are good alternative source of food with high nutritional content for instance proteins, lipids, fibres, carbohydrates and minerals ( $\mathrm{Mg}, \mathrm{Ca}, \mathrm{Zn}, \mathrm{P}$ and $\mathrm{Fe}$ ). Therefore, this study revealed that some of the most traditionally consumed seeds are highly nutritious in particular $C$. pepo which can meet some of the Recommended Daily Allowance (RDA) of micronutrients such as $\mathrm{Ca}$ and $\mathrm{P}$ [16]. Importantly, these results strongly suggest that the studied $C$. реро seeds if adequately consumed in sufficient quantities would immensely improve human nutritional requirement. Therefore, this alone can also greatly contribute to household food security and nutritional requirements which consequently enhance normal growth and adequate protection against diseases and malnutrition in most vulnerable groups of the society such as children, pregnant/lactating mothers and elderly people. However, it is of significance importance to further profile the quality of the oil and protein of C. pepo seeds so as to assure their essentiality and availability to the human body. Investigation should also be carried to ascertain the presence of other bioactive and anti-nutritional factors that might be present in these seeds. Once this information is availed this might otherwise trigger wider cultivation and consumption of $C$. pepo seeds.

\section{Acknowledgements}

We acknowledge the entire team of researchers involved in this work for the commitment and diligence in executing their various assignments consequently making it successful. Above all, we would also like to appreciate the Harare Institute of Technology, which supported our work throughout.

\section{References}

[1] Achu, M. B. (2005). "Nutritive value of some Cucurbitaceae oilseeds from different regions in Cameroon. , 4(November), pp.1329-1334.".

[2] Achu, M. B. (2013). "Chemical evaluation of protein quality and phenolic compound levels of some Cucurbitaceae oilseeds from Cameroon. , 12(7), pp.735-743.".

[3] Ali, A. and N. Saddiq (2012). "Antifungal and prophylactic activity of pumpkin ( Cucurbita moschata ) extract against Aspergillus flavus and aflatoxin B1. , 6(41), pp.6941-6947.".

[4] AOAC (1990). "Official methods of analysis, 14th edition, Association of Official Analytical Chemists, Washington DC. USA, p76-86."

[5] AOAC (2000). "Official Methods of Analysis, $17^{\text {th }}$ edition, Association of Official Analytical Chemists, Washington DC. USA.".

[6] Applequist, W. L., B. Avula, B. T. Schaneberg, Y. H. Wang and I. A. Khan (2006). "Comparative fatty acid content of seeds of four Cucurbita species grown in a common (shared) garden. J Food Compost Anal, 19:606-11.". 
[7] Balkaya, A., M. Özbakır and O. Karaağaç (2010). "Pattern of variation for seed characteristics in Turkish populations of Cucurbita moschata Duch. African Journal of Agricultural Research, 5(10), 1068-1076.".

[8] Bonjour, E. 1., W. S. Fargo and P. E. Renser (1990) "Positional preference and squash bugs among cucurbits in oklahoma. J. Entomol. Soc. Am., 83(3): 943-947."

[9] Chigwe, C. F. B. and V. W. Saka (1994). "Collection and characterization of Malawi pumpkin germplasm. Zimbabwe Journal of Agricultural Research 32: 139-147.".

[10] Curtin, L. S. M. and M. Moore (1997). "Healing Herbs of the Upper Rio Grande: Traditional Medicine of the Southwest, Western Edge Press, Santa Fe, New Mexico.".

[11] El Zawane Kamarudin, Q. U. A., A. B. M. Helaluddin and Z. N. M. Sirajudin (2014). "Studies on bactericidal efficacy of pumpkin (Cucurbita moschata Duchesne) peel. Journal of Coastal Life Medicine, 2(2), 146-153.".

[12] FAO (2002). "FAO. Food energy: methods of analysis and conversion factors. FAO Ed, Rome, Italy.".

[13] Govindani, H., A. Dey, L. Deb, S. P. Rout, S. D. Parial and A. Jain (2012). "Protective Role Of Methanolic And Aqueous Extracts Of Cucurbita moschata Linn. Fruits In Inflammation And Drug Induced Gastric Ulcer In Wister Rats.International Journal of PharmTech Research, 4(4).".

[14] Hou, X. and B. T. Jones (2000). "Inductively coupled plasma/Optical Emission Spectrometry In Encyclopedia of Analytical Chemistry R.A. Meyers (Ed.) pp. 9468-9485, Ó John Wiley \& Sons Ltd, Chichester, USA.".

[15] http://www.containerhandbuch.de/chb_e/scha/index.html?/c hb_e/scha/scha_17_03.html \{accessed on 28/05/2014\}

[16] http://www.lenntech.com/recommended-daily-intake.htm \{accessed on $28 / 05 / 2014\}$

[17] Isaboke, H. N., P. Mshenga and M. Saidi (2012). "The Effect of Butternut Squash (Cucurbita moschata) on the Incomes of the Small-Holders in Suba District, Kenya. Asian Journal of Agricultural Sciences 4(5): 319-324."

[18] Kim SR, Ha TY, Song HN, Kim YS, Park YK. Comparison of Gourd specie, National Institute of Food Department Korea (1997)

[19] Kwembeya, E. G. and R. Takawira (2002). " A Checklist of Zimbabwean Vernacular plant names, $2^{\text {nd }}$ Edition, National herbarium and Botanic Garden, Harare, Zimbabwe.".

[20] Lazos, E. S. (1992). "Certain functional properties of defatted pumpkin seed flour. Plant Foods Hum Nutr, 42:257-73.".

[21] Loukou, A. L. (2007). " Macronutrient composition of three cucurbit species cultivated for seed consumption in Côte d' Ivoire. , 6 (March), pp.529-533.".

[22] Ndoro, O. F. (2007). "Indigenous knowledge of the traditional vegetable pumpkin ( Cucurbita maxima / moschata ) from Zimbabwe. , 2 (December), pp.649-655.".

[23] Pandit, M. K., \& Acharya, S. Potential of minor cucurbits for sustainability and livelihood support in west Bengal. J. Agrofor. Environ. 2(2): 209-212

[24] Sadiq, S., T. Izuagie, M. Shuaibu, M. I. Dogoyaro, A. Garba and S. Abubakar (2013). "The Nutritional Evaluation and Medicinal Value of Date Palm (Phoenix dactylifera), International Journal of Modern Chemistry, 4(3): 147-154."

[25] Wang, S.-Y. (2012). "Pumpkin (Cucurbita moschata) fruit extract improves physical fatigue and exercise performance in mice. Molecules (Basel, Switzerland), 17(10), pp.11864-76. Available at: http://www.ncbi.nlm.nih.gov/pubmed/23047485.".

[26] Wolfe, R.R., and Miller, S.L. 2008. The Recommended Dietary Allowance of protein. The Journal of the American Medical Association, 299 (24), 2891-93

[27] Yang, X., Y. Zhao and Y. Lv (2007). "Chemical composition and antioxidant activity of an acidic polysaccharide extracted from Cucurbita moschata Duchesne ex Poiret. Journal of agricultural and food chemistry, 55(12), 4684-4690.".

[28] Zanish, A., Workneth, T.S and Woldetsadk, K. (2013), Effects of accessions on the Chemical quality of fresh pumpkin, African Journal of Biotechnology, 12 (51), 7092-7098. 